\title{
Log10 50 Percent Cell Culture Infective Dose per Dose
}

National Cancer Institute

\section{Source}

National Cancer Institute. Log 1050 Percent Cell Culture Infective Dose per Dose. NCI

Thesaurus. Code C70485.

A logarithmic-scale (base 10) potency unit for measuring infectious activity of a biologic product or infectious agent preparation equal to the potency at which one dose of infectious material contains one 50 percent cell culture infective dose. 